\title{
Determinants of Commercial Bank Efficiency? Evidence from Bangladesh
}

\author{
Abdus Samad \\ Utah Valley University
}

First, this paper investigated the technical efficiency (TE) of the banking industry of Bangladesh during 2008-2015 employing the two stage Data Development Analysis (DEA) method. Results of the overall technical efficiency (TE) score ranged between 96.7 percent and 98.6 percent during 2008-2012 which suggested that the technical inefficiency of the banking sector of Bangladesh ranged between 3.3 percent and 1.4 percent. The results of the pure technical efficiency (PTE) score known as managerial efficiency showed that the average (PTE) of the banking industry fluctuated between 98.1 percent and 99.3 percent during 2008-2012. The PTE efficiency dominated the TE during 2008-2012. Secondly, the paper applied Tobit regression in determining factors that significantly affected technical efficiencies of the Bangladesh banking industries.

The Probit results of CAMEL and other bank internal factors showed that both the CAMEL model and the CAMEL Plus model provides an important explanation for both TE and PTE. This paper found, among factors, capital adequacy (EQTA), asset quality (LLOSSTA), and bank profitability (ROA) were significant factors for TE and PTE of the Bangladesh banking industry. Among bank internal factors, bank size (logTA) and bank branches (Branch) were significant determinants for bank efficiency. The paper provided the policy implication for bank management.

Keywords: DEA Bank Efficiency, Determinants of Efficiency, Banking Industry, Bangladesh

\section{INTRODUCTION}

Bangladesh seceded from Pakistan and was born in 1971. Since its establishment, there has been a rapid growth of banking sectors. At the time of its birth there no private banks but four nationalized banks, Sonali Bank, Rupali bank, Janata bank, and Pubali bank. Now, there are forty-one banks in the banking industry. The banking sector of Bangladesh comprises of nationalized banks, private foreign and domestic banks. The study of efficiency and the determinants of the efficiency of the banking sector of Bangladesh are important for several reasons.

From a macroeconomic point of view, the efficiency of banks affects the structure and stability of the whole financial system (Rossi et al. 2005). The best example how the efficiency affects nation was the global financial crisis of 20008-2010. There were large bank failure in the U.S. The inefficiency of banks increases the cost of intermediation and harms the allocation of funds and the profitability of bank leading bank failure (Samad, 2014). The increased efficiency of banks in deposit mobilization and loan advancing 
is a key to successful entrepreneurs for enhancing the economic growth of a country (Schumpeter, 1911). The efficiency study of Bangladesh banking is important for several reasons:

First, the efficiency of the productivity of banks is of great interest to public authorities supervising and regulating banks, bank managements, and bank depositors and borrowers. Each of them is interested to know the productive efficiency of banks. In a competitive market environment, bank depositors and borrowers are interested to know the efficiency status of individual banks before they deposit their hardearned savings. The borrowers choose the banks which are more efficient, efficient in advancing loans and profitability.

Second, there is tremendous growth of banks and financial institutions in Bangladesh. When Bangladesh was born in 1971, there was no private bank. The five banks that Bangladesh inherited from Pakistan at the time of liberation were Sonali Bank, Rupali Bank, Janata Bank, Agrani Bank, and Pubali bank. These banks were nationalized by the-then government of Bangladesh and became the public sector banks. When the privatization policy was introduced in 1982, there was just one private domestic bank (Pubali Bank) in Bangladesh. Currently, there are forty-one private banks excluding four government owned banks

Third, the determination of factors affecting the efficiency of banks is very important to bank management. There are various bank internal factors as well as bank external factors affecting bank production efficiency. The identification of these factors is very important for policy prescription for bank management and bank regulators.

Fourth, the identification of efficiency determinants has serious implications in terms of bank resource allocation. Bank resources are scarce and have opportunity costs. In the competitive market, a bank cannot afford to have random allocation of scarce resources. Conscious and efficient allocation of resources is possible only when the efficiency factor/s are determined.

This paper aims to contribute to banking literature by identifying factors that were significant in determining the technical efficiency (TE) and pure technical efficiency (PTE) of the banking industry of Bangladesh.

This paper is organized as: Section 2 provides the review of literature. Data and methodology are described in Section 3. Empirical results and conclusions are provided in Section 4.

\section{REVIEW OF LITERATURE}

There were substantial studies for the banking efficiencies in the Western world. Among the prominent studies were Berger and Humphery (1992), Berger and Humphery (1997), Aly et al (1990), Barr et al (2002), Merger and Mester (2003), Casu and Girardone (2002), and Andries and Cocris (2010). They provided a significant contribution in dealing with the efficiency studies of the banking firm. However, their studies focused on the banking firms of the U.S. and Europe.

The number of bank efficiency studies of the less developed countries (LDC) is, however, limited. The study on banking efficiency of the Southeast Asian countries, including Bangladesh, are very few and almost non-existent.

Kumar and Gulati (2008) examined bank efficiencies: technical efficiency (TE), pure technical (PTE), and scale efficiencies (SE) of the 27 public sector banks of India just for 2004 and found public sector banks operated at 88.5 percent level of TE i.e. the inefficiency was 11.5 percent. Only 7 banks were technically efficient. The regression results of the paper found that the off-balance activities positively affected the Indian bank efficiency.

El-gamal and Inanoglu (2004) estimated the comparative cost efficiency of the Turkish banks for the period 1990-2000 using the data envelopment analysis (DEA) method. They found that the Islamic banks were more efficient due to Islamic banks' asset-based financing.

Samad (2004) compared the performance of Islamic banks and conventional commercial banks of Bahrain with respect to (a) profitability, (b) liquidity, and (c) capital management. A comparison of 11 financial ratios for the period 1991-2001 found that there was no difference in profitability and liquidity performance between Islamic and conventional banks for that period. 
Sufian and Majid (2006) investigated the comparative efficiency of the foreign and domestic banks of Malaysia during 2001-2005. They found that banks' scale inefficiency dominated pure technical efficiency during the period. They also found that the foreign banks had higher technical efficiency than the domestic banks.

Sufian (2009) estimated the various efficiencies and the determinants of these efficiencies of the Malaysian banks. His studies found that the efficiencies were negatively related to bank expenses and economic conditions, while the efficiencies were positively related to loan intensity.

Rammohan and Roy (2004) and Sarkar et al. (1998) examined Indian banking sector efficiency. Rammohan and Roy found that public sector banks are more efficient than the private sector banks in India. In another study, Kumbhakar and Sarkar (2003) used a cost efficiency approach for measuring bank efficiency and also concluded that private sector banks had higher levels of efficiency contrasted to public sector banks in that country.

Another group of Indian scholars used the DEA approach in measuring bank efficiency, including Saha and Ravi Shankar (2000), Bhattacharyya et al. (1997) and Sanjeev (2006). Bhattacharyya et al. (1997) determined in their study that public sector banks were the best performing banks in India during the late 1980s and early 1990s. Shanmugam and Das (2004) used a stochastic frontier analysis (SFA) process for measuring technical efficiencies of Indian commercial banks and found that a group of state banks were more efficient than a comparable group of foreign banks during a period from 1992-1999.

Andries and Cocris (2010) analyzed the comparative efficiency of banks in several southern European countries during the period of 2000-2006 using both DEA and SFA analytic processes. They found that the banks in Romania, the Czech Republic, and Hungary all operated at relatively low levels of technical efficiency.

Samad (2009) evaluated the efficiency of the banks of Bangladesh using data of 2000 and found that the average efficiency of those banks was 69.6. However, this study focused on the TE only for the year 2000 .

Samad (2007) also examined the comparative performance of foreign banks verses domestic banks in Bangladesh using various financial ratios of bank performance and found no difference in profit performance between domestic banks and foreign banks in the period 2000-2001. In another analysis, Samad (2010) estimated the technical efficiency of Grameen bank of Bangladesh, established by Nobel Laureate Dr. Muhammad Yunus, and found that the average efficiency ranged between $91 \%$ and $98 \%$.

Samad (2013) investigated the efficiency of Islamic banks using the time varying Stochastic Frontier function on the Islamic banks of 16 countries. Mean efficiencies between the pre global financial crisis and the post global crisis were estimated at 39 and 38 percent respectively and the difference was not statistically significant.

The current study is different from the previous studies (Samad 2009, 2010, 2013) in several ways. First, this study is extended to cover five years during 2008-2012, not just the one year. Second, this study focuses to estimate the pure technical efficiency (PTE), technical efficiency (TE), and scale efficiency (SE), compared to TE only. Third, this study estimated efficiencies using intermediary approach, valueadded approach, and operating approach. Whereas the previous studies used just the intermediary approach.

\section{DATA, METHODOLOGY, AND SPECIFICATION OF VARIABLES}

\section{Data}

This study covers the period 2008-2012. The input and output data of all variables related to efficiency estimates were obtained from Bank-Insurance and Financial Institutions Activities published by the Division of Banks and Financial Institutions of the Ministry of Finance, Government of Bangladesh. The value of variables is in local currency (TK) and in millions except labor. Table A, in Appendix 1, provides the descriptive statistics of the input and output used in this study 


\section{Methodology}

First, DEA was employed in estimating the efficiency score of the Bangladesh banking industry during 2008-2012. Once efficiency scores were obtained, the paper, secondly, applied Tobit regression, first, on yearly technical efficiency and then on the pooled technical efficiency for determining the significant factors affecting efficiencies.

There are two approaches for obtaining the efficiencies of any decision making unit (DMU). (i) Stochastic frontier function/method (SFM) developed by Aigner, Lovell, and Schmidt (1977) and later refined by Pitt and Lee (1981) and Batties and Colie (1992). The SFM is a parametric approach. (ii) Data Envelope Analysis (DEA) method. DEA is a linear programming and a non-parametric method. The DEA was originally proposed by Farrell (1957) and was first used by Charnes, Cooper, and Rhodes (CCR) (1978). The model proposed by CCR assumed constant returns to scale (CRS). Under the CCR model, DEA was used to measure the efficiency of each DMU as the maximum ratio of weighted outputs to weighted inputs. The CCR model presupposes no significant relationship between scale efficiency (SE) of operation and technical efficiency (TE) under the assumption of constant returns to scale (CRS) and thus provides the overall technical efficiency (OTE) also called allocative/economic efficiency.

Banker, Charnes, and Cooper (BCC) (1984) replaced the CRS assumptions by the variable returns to scale (VRS) assumption. In fact, the CRS assumption is not justifiable because all DMUs do not operate at optimum scale. Firms or DMUs may operate under economies of scale (i.e. increasing returns to scale, IRS) or diseconomies of scale (i.e. decreasing returns to scale, DRS). So, the estimated measure of TE under the assumption of optimum scale (CRS) is contaminated with scale efficiencies. This leads to the extension of another DEA model by Banker, Charnes, and Cooper (BCC) (1984) in which variable returns to scale (VRS) were assumed to estimate the efficiency of DMUs. The VRS assumption of BCC model provides the measures of pure technical efficiency (PTE) which is a measure of TE devoid of scale efficiency (SE) effect. Thus, scale inefficiency of a DMU occurs when PTE score of a DMU is not equal to TE score.

The difference between the CCR and BCC models can be illustrated by the following graph:

FIGURE 1

\section{CRS AND VRS EFFICIENCY FRONTIERS}

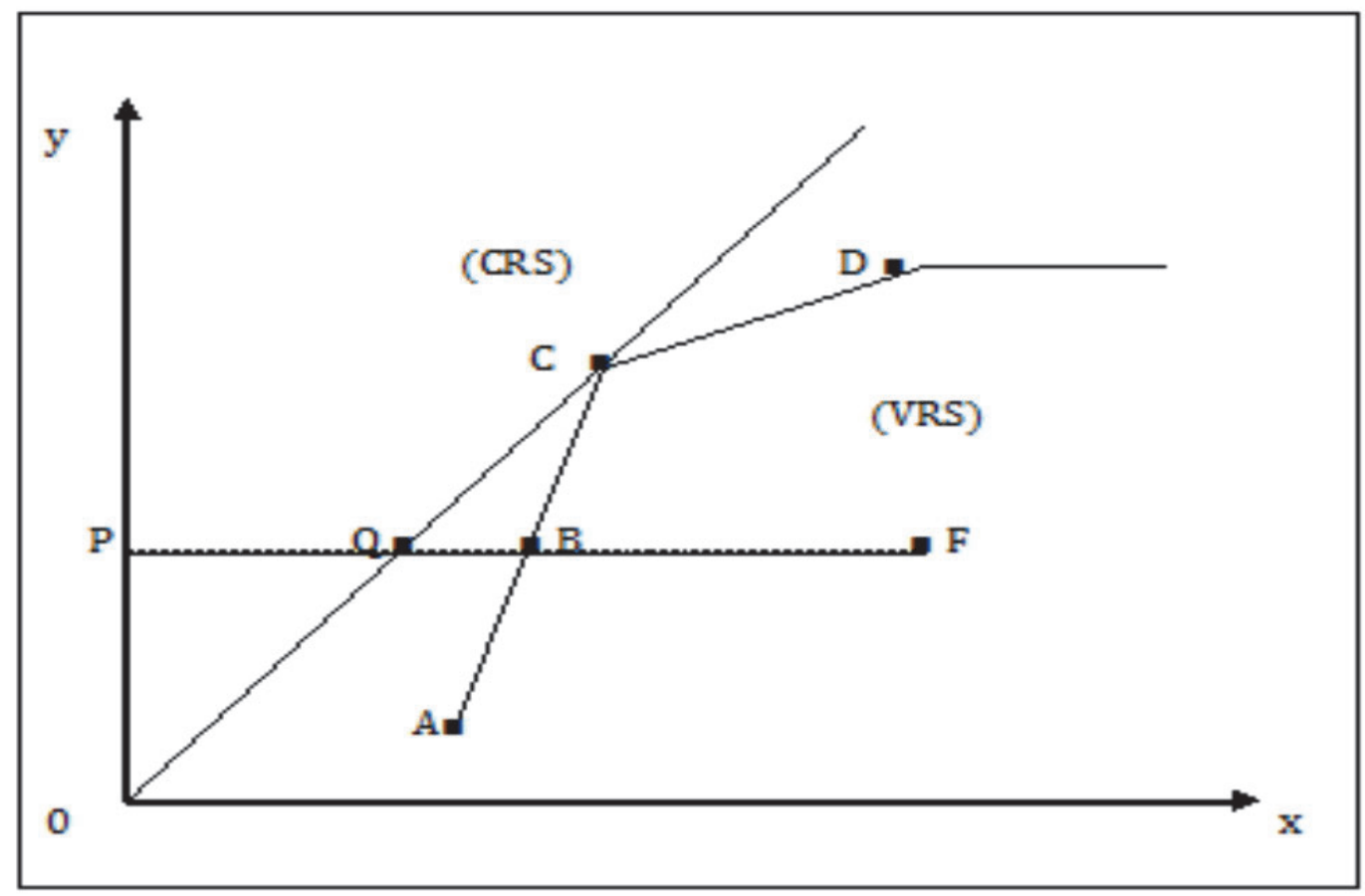

Coelli et al, 2005 
The line through the points $\mathrm{Q}$ and $\mathrm{C}$ represents the CRS efficiency frontier and the curve (ABCD) represents the VRS efficiency frontier. Each DMU that is on the frontier is technically efficient. For this reason, the particular DMU "F" is technically inefficient. When we refer to the CRS frontier, the distance FQ measures the technical inefficiency of the DMU "F". However, when we consider the VRS frontier, the technical inefficiency of the DMU "F" is only the distance FB. The difference between the CRS and the VRS frontiers is the distance QB which is a measure of scale inefficiency.

The overall technical efficiency score (under the CRS frontier): $\mathrm{TE}_{\mathrm{CRS}}=\mathrm{PQ} / \mathrm{PF}$

The pure technical efficiency score (under VRS frontier): $\mathrm{TE}_{\mathrm{VRS}}=\mathrm{PB} / \mathrm{PF}$

The scale efficiency score: $\mathrm{SE}=\mathrm{PQ} / \mathrm{PB}$

From this, we can deduce that $\mathrm{TE}_{\mathrm{CRS}}=\mathrm{TE}_{\mathrm{VRS}} \mathrm{x}$ SE which means that the overall technical efficiency (OTE) of a particular DMU is the product of two efficiencies: pure technical efficiency (PTE) and scale efficiency (SE). Suppose that there are DMUs to be evaluated. Each DMUj, $j=1, \ldots ., n$ uses $m$ different inputs to produce $s$ different outputs, noted $(r=1, \ldots, s)$. The technical efficiency score for a particular DMU, called DMUo, is determined by solving the following linear programming problem. The technical efficiency score $\theta$ for a particular DMU, called DMUo, is determined by solving the following linear programming problem:

$$
\begin{array}{rc}
\theta^{*}=\operatorname{Min} \theta & \\
\text { s.t. } \sum_{j=1}^{n} \lambda_{j} x_{i j} \leq \theta x_{i o} & i=1, \ldots \ldots, m ; \\
\sum_{j=1}^{n} \lambda_{j} y_{r j} \geq y_{r o} & r=1, \ldots \ldots, s ; \\
\lambda_{j} \geq 0 & j=1, \ldots \ldots, n ;
\end{array}
$$

$\theta<1$ Means that the evaluated DMU is technically inefficient. $\theta=1$ Indicates a point on the frontier and hence a technically efficient DMU. In order to estimate the efficiency scores of all the DMUs in the sample, the above problem must be solved $\mathrm{n}$ times, once for each DMUj, $j=1, n$ (Coelli et al., 2005). The efficiency score, $\theta$ (PTE), TE, and SE of each DMU (each bank) is presented in the empirical section.

This paper applies BCC (1984) DEA method in estimating the variable returns to scale efficiencies of DMU. The BCC input-output model which is estimated in this paper to evaluate the relative to frontier is:

$\max \mathrm{z}=u y_{\mathrm{j}}$

$\mathrm{v}, \mathrm{y}$

Subject to $v x j=1,-{ }^{v} \mathrm{X}+u_{\mathrm{Y}} \leq 0, v \geq 0, u_{\geq 0}, u_{\mathrm{j}}$ free from sign, where a set of observed DMUs \{

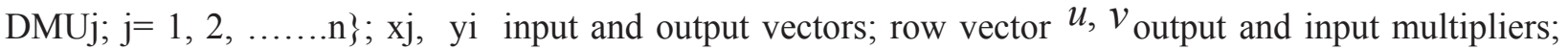
and $\mathrm{X}$ and $\mathrm{Y}$ input and output matrices. Note that the goal of input oriented DEA model is to minimize the use of input, relative to virtual output given condition that no DMU can operate beyond the production possibility frontier and the constraints of non-negative weights.

Using the duality in linear programming, as the most DEA program is a dual form, one can write the above (1) in an envelopment which can simplify the burden of calculation as:

$\min \theta$

$\varnothing, \lambda$

Subject to $\theta$ is a scalar and $\lambda$ is a I $x$ I semi-positive vector of constraint, $\theta x j-X \lambda \geq 0, Y \lambda \geq y j$. The value of $\theta$ obtained is the efficiency score of the $i$-th DMU. It satisfies: $\theta \leq 1$, with a value of 1 indicating a point on the frontier and is thus technically efficient firm/DMU, according to Farrell (1957). 
The efficiency score, $\theta$ (PTE), TE, and SE of each DMU (each bank) is presented in the empirical section.

\section{Specification of Variables}

The specification variables, dependent and independent, depends on which are banks' inputs and which are banks' outputs. The physical measures of output and input are distinct in many industries. For examples, in agriculture, the output is paddy, wheat or corn and is measured in tons or kg. Inputs are land, labor, and capital. In electricity, the output is kilowatt-hours of electricity. Inputs are the number of workers and the value of electric generators.

There is no agreement in the physical measures of output and input in the banking sector. Banks are multi-product firms and produce a variety of products and services as loans to customers, safekeeping, intermediation, and accounting services for deposits (Benston and Smith, 1976). Some have argued that a bank's primary product is loans. From an asset point of view, the production of deposit services is essentially viewed as inputs which are used to make loans (Sealey and Lindley, 1977).

There are four approaches found in the literature. They are: (i) Intermediation approach, (ii) Production approach, (iii) Operating approach, and (iv) Value added approach.

This paper uses the intermediate approach which suggests that banks primarily act as an intermediary between savers (lender) and borrowers, i.e. banks collect deposits from the savers and invest in income generating assets. In this approach, loans and advances and investment in securities are considered as outputs of banks whereas labor, capital and deposits are considered as inputs.

\section{Estimated Efficiency Model}

Based on the definition of the intermediate method, provided above, the estimated model is:

$\operatorname{Loan}_{\text {it }}=\alpha_{0}+\alpha_{1} \mathrm{~L}_{\mathrm{it}}+\alpha_{2} \mathrm{~K}_{\mathrm{it}}+\alpha_{3} \mathrm{Dep}_{\mathrm{it}}$

where $\mathrm{L}=$ labor of $\mathrm{i}^{\text {th }}$ bank in $\mathrm{t}^{\text {th }}$ period, $\mathrm{K}=$ Capital of $\mathrm{i}^{\text {th }}$ bank in $\mathrm{t}^{\text {th }}$ period, and Dep $=$ Deposit of $\mathrm{i}^{\text {th }}$ bank in $\mathrm{t}^{\text {th }}$ period. All values are in million Taka, the local currency of Bangladesh, expressed in natural log $(\mathrm{LN})$.

\section{Estimated Tobit Model}

Once the efficiency of each DMU is obtained, the Tobit model is applied to determine the significance of the factors that determine the efficiency of banks. Two models are estimated for determining the significant factors: (1) CAMEL model (2) CAMEL PLUS model. The CAMEL Plus model consists of CAMEL variables along with bank specific internal variables. The estimated CAMEL model and CAMEL plus model are provided in (EQ 2) and (EQ 3) respectively:

$$
\begin{aligned}
& \text { Eff }_{\text {bkit }}=\alpha_{0}+\alpha_{1} \text { EQTA }_{\text {it }}+\alpha_{2} \text { LLOSTA }_{i t}+\alpha_{3} \text { ROA }_{\text {it }}+\alpha_{5} \text { EXPSTA }_{i t}+\alpha_{6} \text { Loandep }_{i t}+v_{i t} \\
& \text { Eff }_{\text {bkit }}=\alpha_{0}+\alpha_{1} \text { EQTA }_{\text {it }}+\alpha_{2} \text { LLOSTA }_{i t}+\alpha_{3} \text { ROAit }+\alpha_{5} \text { EXPSTA }_{i t}+\alpha_{6} \text { Londe }_{i t} \\
& +\alpha \log A_{i t}+\alpha_{7} \text { BRNC }_{\text {it }}+v_{i t}
\end{aligned}
$$

where $\mathrm{Eff}_{\text {bkit }}=\mathrm{i}^{\text {th }}$ bank efficiency in $\mathrm{t}^{\text {th period }}, \mathrm{EQTA}_{\mathrm{it}}=\mathrm{i}^{\text {th }}$ bank equity capital as a percentage of total assets in $\mathrm{t}^{\text {th period }}$, LLOSTA $_{i t}=\mathrm{i}^{\text {th }}$ bank's total loan loss as a percentage of total assets in $\mathrm{t}^{\text {th period }}, \mathrm{ROA}_{\mathrm{it}}=\mathrm{i}^{\text {th }}$ bank net profits as a percentage of total assets in $t^{\text {th period }}$, EXPSTA $A_{i t}=i^{\text {th }}$ bank total operating expenses as a percentage of total assets in $\mathrm{t}^{\text {th period }}$, Loande $\mathrm{p}_{\mathrm{i}}=\mathrm{i}^{\text {th }}$ bank stotal loans as a percentage of total deposits in $\mathrm{t}^{\text {th }}$ period, $\log \mathrm{TA}_{\mathrm{it}}=$ natural $\log$ of bank's total assets, and $\mathrm{BRNC}_{\mathrm{it}}=$ number of branch of $\mathrm{i}^{\text {th }}$ bank in $\mathrm{t}^{\text {th }}$ period.

The definition of all variables of model 2 and model 3 and the expected impacts of these variables on the efficiency of banks are provided in Table 1 
TABLE 1

INDEX OF CAMEL AND CAMEL PLUS VARIABLES AND THEIR EXPECTED IMPACT ON EFFICIENCY

\begin{tabular}{|l|l|l|}
\hline Variables & Index of Measure & Expected relation with efficiency \\
\hline Capital Adequacy & EQ/TA: & $\begin{array}{l}(+,-) \\
\text { Bank efficiency may increase if the } \\
\text { equity capital is transformed into loan } \\
\text { advances and investments, otherwise } \\
\text { it may decrease efficiency }\end{array}$ \\
\hline Asset Quality & LLOSS/TA & $\begin{array}{l}\text { Loan losses are heavy burdens on } \\
\text { bank's assets. It decreases bank's } \\
\text { efficiency. }\end{array}$ \\
\hline Management Quality & ROA & $\begin{array}{l}(+) \\
\text { Bank efficiency increases with higher } \\
\text { profits/return on }\end{array}$ \\
\hline Efficiency (cost) & $\begin{array}{l}(-) \\
\text { A higher cost to generate per dollar } \\
\text { asset decreases bank efficiency }\end{array}$ \\
\hline Liquidity Index & $\begin{array}{l}(+) \text { hXPNSE/TA } \\
\text { A higher percentage of loans out } \\
\text { deposit increases efficiency in loan } \\
\text { production by decreasing bank's } \\
\text { liquidity }\end{array}$ \\
\hline Bank Size & Loan/Deposit & $\begin{array}{l}\text { Efficiency may increase if economies } \\
\text { of scale arise when the bank size is } \\
\text { optimum. Otherwise efficiency } \\
\text { decreases when a bank size is large } \\
\text { and generates diseconomies of scale }\end{array}$ \\
\hline & Natural log of TA &
\end{tabular}

\section{EMPIRICAL RESULTS}

\section{Technical Efficiencies (TE)}

The TE is the combination of pure technical efficiency (PTE) and scale efficiency (SE). TE is also called the overall technical efficiencies. Thus, there are two sources of technical inefficiencies (TIE). It may arise due to pure technical inefficiencies (PTIE) i.e. misallocation of inputs and inefficiencies or it may arise due to inappropriate bank size, i.e. scale inefficiency (SIE). The TE score of the banking industry of Bangladesh is provided in Table 2 
TABLE 2

DESCRIPTIVE STATISTICS OF TE SCORE OF BANGLADESH BANKING INDUSTRY DURING 2008-2012*

\begin{tabular}{llllll}
\hline \multicolumn{1}{c}{ Variables } & \multicolumn{5}{c}{ Year } \\
\hline Mean & 2008 & 2009 & 2010 & 2011 & 2012 \\
Median & 0.967166 & 0.986495 & 0.981032 & 0.979172 & 0.974192 \\
Maximum & 0.965804 & 0.986716 & 0.985497 & 0.980783 & 0.973296 \\
Minimum & 1.000000 & 1.000000 & 1.000000 & 1.000000 & 1.000000 \\
Std. Dev. & 0.946490 & 0.960001 & 0.932115 & 0.911365 & 0.943452 \\
Skewness & 0.012411 & 0.012443 & 0.018957 & 0.018231 & 0.017978 \\
Kurtosis & 1.206962 & -0.568119 & -1.000303 & -1.374649 & 0.085426 \\
Efficient banks & 3.756216 & 2.212983 & 2.975130 & 6.004997 & 1.716607 \\
& $3(8 \%)$ & $9(23 \%)$ & $10(24 \%)$ & $8(20 \%)$ & $6(14.6 \%)$ \\
Below Mean & $20(54 \%)$ & $26(68.4 \%)$ & $15(37.5 \%)$ & $18(45 \%)$ & $22(53.6 \%)$ \\
Above Mean & $17(49.9 \%)$ & $12(31.6 \%)$ & $25(62.5 \%)$ & $22(55 \%)$ & $19(46.4)$ \\
& & & & & \\
IRS Banks & 0 & $10(26 \%)$ & $8(20 \%)$ & $3(0.7 \%)$ & $4(0.1)$ \\
CRS Banks & $3(17 \%)$ & $9(24 \%$ & $10(25 \%)$ & $8(20 \%)$ & $6(0.1)$ \\
DRS Banks & $34(83 \%)$ & $19(50 \%)$ & $22(55 \%)$ & $29(72.3 \%)$ & $31(80 \%)$ \\
Total Banks & 37 & 38 & 40 & 40 & 41 \\
\hline
\end{tabular}

*number in ( ) is the percentage of banks.

The average TE of the banking sector of Bangladesh, in Table 2, was relatively stable and it fluctuated between 96.7 percent and 98.6 percent during 2008-2012. This suggests that the technical inefficiency of the banking sector of Bangladesh ranged between 3.3 percent and 1.4 percent. Similar results were found for the median. The median technical efficiency ranged from 96.6 percent to 98.6 percent.

The percent of full (100\%) technically efficient banks was few and it fluctuated between 8 percent and 24 percent of the total banks during 2008-2012. The highest number of technically efficient banks fluctuated between 3 banks and 10 banks.

A large number of banks operated below the mean TE. The number of banks operating below the mean technical efficiency ranged between 15 banks and 20 banks. i.e. from 37 percent to 68.4 percent banks of the banking sector of Bangladesh operated below the mean TE during 2008-2012.

Banks operating under the decreasing returns scale (DRS) dominate the banking sector of Bangladesh. That is, banks were not scale efficient. They were too large. From 50 percent to 83 percent of the banks of Bangladesh operate under the DRS compared to 0 percent to 26 percent of the banks which operated in the increasing returns to scale (IRA) during 2008-2012.

\section{Pure Technical Efficiencies (PTE)}

The PTE is called the managerial efficiency. The $(1-\mathrm{PTE})$ is the pure technical inefficiency (PTIE) which results from managerial underperformance. PTIE arises due to poor input utilization (Kumar and Gulati (2008). The descriptive statistics of the PTE score of the banking industry of Bangladesh is provided in Table 3. 
TABLE 3

DESCRIPTIVE STATISTICS OF PTE SCORE OF BANGLADESH BANKING INDUSTRY DURING 2008-2012

\begin{tabular}{llcccc}
\hline \multicolumn{5}{c}{ Year } \\
\hline Variables & 2008 & 2009 & 2010 & 2011 & 2012 \\
Mean & 0.986654 & 0.993064 & 0.987341 & 0.983189 & 0.981339 \\
Median & 0.988132 & 0.998993 & 0.989184 & 0.985270 & 0.983356 \\
Maximum & 1.000000 & 1.000000 & 1.000000 & 1.000000 & 1.000000 \\
Minimum & 0.956747 & 0.962633 & 0.956286 & 0.911365 & 0.944911 \\
Std. Dev. & 0.011685 & 0.010376 & 0.013707 & 0.019207 & 0.018124 \\
Skewness & -0.712295 & -1.447022 & -0.800070 & -1.600650 & -0.361089 \\
Kurtosis & 2.651986 & 3.951550 & 2.622721 & 6.160240 & 1.708585 \\
Efficient banks & $7(18.9 \%)$ & $18(47.3 \%)$ & $17(42.5 \%)$ & $13(32.5 \%)$ & $15(36.5 \%)$ \\
\% Below Mean & $34(91.8 \%)$ & $20(52.6 \%)$ & $11(27.5 \%)$ & $18(45 \%)$ & $19(46.3 \%)$ \\
\% Above Mean & $3(8.2 \%)$ & $18(47.4 \%)$ & $29(72.5 \%)$ & $22(55 \%)$ & $22(53.7 \%)$ \\
Total Banks & 37 & 38 & 40 & 40 & 41 \\
\hline
\end{tabular}

*number in ( ) is the percentage of banks.

The average pure technical efficiency (PTE) of the banking sector of Bangladesh, in Table 3, was relatively stable and it fluctuated between 98.1 percent and 99.3 percent during 2008-2012. This suggests that the managerial inefficiency of the banking sector of Bangladesh ranged between 0.7 percent and 1.9 percent. Similar results were found for the median PTE. The median PTE ranged from 98.3 percent to 99.9 percent.

The percentage of marginally efficient banks of Bangladesh ranged from 18.9 percent to 47.3 percent during 2008-2012.

A large percentage of banks operated below the mean PTE. From 27.5 percent to 91.8 percent of the banks of Bangladesh operated below the mean efficiency during 2008-2012. This suggests that there was a great scope of improving managerial (PTE) efficiency.

A comparative summary of TE score and PTE score reveals, from Table 2 and Table 3, the following: (1) The PTE of the banks of Bangladesh dominates the TE in the banking sector of Bangladesh. That is, banks of Bangladesh were managerially more efficient than TE. This is reflected from the fact mean PTE ranged from 98.1 percent to 99.3 percent whereas the mean TE fluctuated between 96.7 percent and 98.6 percent. (2) The banking sector of Bangladesh is dominated by the DRS. From 50 percent to 83 percent of banks of Bangladesh operated under the DRS during 2008-2012 compared to 0 percent 26 percent of banks which operated under the IRS.

\section{TE Tobit Regression Results}

Two Tobit regressions were run. The first Tobit regression was run for determining the significance of CAMEL variables. The results of the first Tobit model was presented in Table 4. The second Tobit was run in determining the significance of CAMEL Plus model. The results of this CAMEL Plus model is provide in Table 5. 
TABLE 4

TE REGRESSION RESULTS OF CAMEL MODEL

\begin{tabular}{|c|c|c|c|c|c|}
\hline & Year & & & & \\
\hline Variables & 2008 & 2009 & 2010 & 2011 & 2012 \\
\hline EQTA & $\begin{array}{l}0.07 \\
(1.78) * * *\end{array}$ & $\begin{array}{l}0.16 \\
(1.86) * * *\end{array}$ & $\begin{array}{l}0.02 \\
(0.59)\end{array}$ & $\begin{array}{l}0.01 \\
(0.43)\end{array}$ & $\begin{array}{l}0.03 \\
(0.93)\end{array}$ \\
\hline LLOSSTA & $\begin{array}{l}-0.01 \\
(-2.75)^{*}\end{array}$ & $\begin{array}{l}-0.01 \\
(-0.85)\end{array}$ & $\begin{array}{l}-0.01 \\
(-1.20)\end{array}$ & $\begin{array}{l}-0.03 \\
(-1.81) * * *\end{array}$ & $\begin{array}{l}-0.03 \\
(-1.69) * * *\end{array}$ \\
\hline ROA & $\begin{array}{l}0.31 \\
(2.19)^{* *}\end{array}$ & $\begin{array}{l}-0.27 \\
(-0.91)\end{array}$ & $\begin{array}{l}0.17 \\
(0.66)\end{array}$ & $\begin{array}{l}0.50 \\
(1.86)^{* * *}\end{array}$ & $\begin{array}{l}0 . .43 \\
(2.08)^{* *}\end{array}$ \\
\hline EXPSTA & $\begin{array}{l}-0.14 \\
(-2.10)^{* *}\end{array}$ & $\begin{array}{l}-0.09 \\
(-0.79)\end{array}$ & $\begin{array}{l}-0.15 \\
(-0.90)\end{array}$ & $\begin{array}{l}-0.24 \\
(-1.47)\end{array}$ & $\begin{array}{l}-0.08 \\
(-0.44)\end{array}$ \\
\hline LOANDEP & $\begin{array}{l}0.08 \\
(3.79) * *\end{array}$ & $\begin{array}{l}0.91 \\
(2.51)^{*}\end{array}$ & $\begin{array}{l}0.03 \\
(1.44) \\
\end{array}$ & $\begin{array}{l}0.02 \\
(0.64) \\
\end{array}$ & $\begin{array}{l}0.02 \\
(0.74) \\
\end{array}$ \\
\hline Constant & $\begin{array}{l}0.91 \\
(46.68) *\end{array}$ & $\begin{array}{l}0.93 \\
(39.65)^{*}\end{array}$ & $\begin{array}{l}0.96 \\
(43.14)^{*}\end{array}$ & $\begin{array}{l}0.97 \\
(33.56)^{*}\end{array}$ & $\begin{array}{l}0.96 \\
(32.45)^{*}\end{array}$ \\
\hline $\begin{array}{l}\text { Log } \\
\text { Likelihood }\end{array}$ & 86.38 & 47.42 & 47.42 & 55.82 & 50.47 \\
\hline $\operatorname{LR~chi~}^{2}(5)$ & 24.34 & 13.65 & 10.85 & 12.09 & 14.08 \\
\hline Prob $>\mathrm{Chi}^{2}$ & 0.0002 & 0.01 & 0.05 & 0.03 & 0.01 \\
\hline Pseudo $\mathrm{R}^{2}$ & -0.16 & -0.16 & -0.12 & -0.12 & -0.16 \\
\hline \# of Obs & 37 & 38 & 40 & 40 & 42 \\
\hline
\end{tabular}

$*=$ significant at 1 percent level, $* *=$ significant at 5 percent level, $* * *=$ significant at 10 percent level

The regression results, in Table 4, supports the CAMEL model. The expected signs of all CAMEL variables were consistent as outlined in Table 1 in all five years during 2008-2012.

All CAMEL factors, capital adequacy (EQTA), asset quality (LLOSSTA), management ability (ROA), cost inefficiency (EXPSTA), and bank liquidity (LOANDEP) were significant determinants for bank technical efficiency in 2008. In 2009, capital adequacy (EQTA) and bank liquidity (LOANDEP) were significant determinants for bank efficiency.

Asset quality (LLOSSTA) and management ability (ROA), were significant determinants for bank TE during 2011 and 2012.

The negative coefficient of asset quality (LLOSSTA) provides policy implication. Since loan losses decreases bank efficiency, bank management should lend extra care in advancing loans.

The low probability of $\mathrm{Chi}^{2}$ supports the log likelihood ratio (LR). 
TABLE5

TE REGRESSION RESULTS OF CAMEL PLUS MODEL

\begin{tabular}{|c|c|c|c|c|c|}
\hline & \multicolumn{5}{|c|}{ Year } \\
\hline Variables & 2008 & 2009 & 2010 & 2011 & 2012 \\
\hline EQTA & $\begin{array}{l}0.16 \\
(3.27)^{*}\end{array}$ & $\begin{array}{l}0.30 \\
(3.26)^{*}\end{array}$ & $\begin{array}{l}0.14 \\
(2.13) * *\end{array}$ & $\begin{array}{l}0.01 \\
(0.39)\end{array}$ & $\begin{array}{l}0.12 \\
(2.27) * *\end{array}$ \\
\hline LLOSSTA & $\begin{array}{l}-0.008 \\
(-1.80)^{* * *}\end{array}$ & $\begin{array}{l}-0.11 \\
(-0.93)\end{array}$ & $\begin{array}{l}-0.01 \\
(-0.78)\end{array}$ & $\begin{array}{l}-0.02 \\
(-1.16)\end{array}$ & $\begin{array}{l}-0.01 \\
(-0.84)\end{array}$ \\
\hline ROA & $\begin{array}{l}0.10 \\
(0.81)\end{array}$ & $\begin{array}{l}-0.20 \\
(-0.80)\end{array}$ & $\begin{array}{l}0.10 \\
(0.39)\end{array}$ & $\begin{array}{l}0.34 \\
(1.22) \\
\end{array}$ & $\begin{array}{l}0.18 \\
(0.95)\end{array}$ \\
\hline EXPSTA & $\begin{array}{l}-0.03 \\
(-0.73) \\
\end{array}$ & $\begin{array}{l}0.09 \\
(0.93)\end{array}$ & $\begin{array}{l}-0.13 \\
(-0.08)\end{array}$ & $\begin{array}{l}-0.19 \\
(-1.28)\end{array}$ & $\begin{array}{l}0.03 \\
(0.22)\end{array}$ \\
\hline LOANDEP & $\begin{array}{l}0.06 \\
(4.26)^{*}\end{array}$ & $\begin{array}{l}0.08 \\
(2.81)^{*}\end{array}$ & $\begin{array}{l}0.02 \\
(0.97) \\
\end{array}$ & $\begin{array}{l}-0.01 \\
(-0.26) \\
\end{array}$ & $\begin{array}{l}-0.01 \\
(-0.56)\end{array}$ \\
\hline $\log \mathrm{TA}$ & $\begin{array}{l}0.02) \\
(5.19)^{*}\end{array}$ & $\begin{array}{l}0.01 \\
(3.55)^{*}\end{array}$ & $\begin{array}{l}0.01 \\
(2.02) * *\end{array}$ & $\begin{array}{l}0.02 \\
(2.08) * *\end{array}$ & $\begin{array}{l}0.02 \\
(2.51)^{*}\end{array}$ \\
\hline Branch & $\begin{array}{l}-0.004 \\
(-2.33)^{* *}\end{array}$ & $\begin{array}{l}-0.004 \\
(-1.32\end{array}$ & $\begin{array}{l}-0.003 \\
(-0.78)\end{array}$ & $\begin{array}{l}-0.01 \\
(-1.84)^{* * *}\end{array}$ & $\begin{array}{l}-0.01 \\
(-2.18) * *\end{array}$ \\
\hline Constant & $\begin{array}{l}0.72 \\
(18.28)^{*}\end{array}$ & $\begin{array}{l}0.71 \\
(11.61)^{*}\end{array}$ & $\begin{array}{l}0.77 \\
(9.07) *\end{array}$ & $\begin{array}{l}0.79 \\
(8.47)^{*}\end{array}$ & $\begin{array}{l}0.72 \\
(6.84)^{*}\end{array}$ \\
\hline $\begin{array}{l}\text { Log } \\
\text { Likelihood }\end{array}$ & 99.54 & 54.34 & 50.41 & 58.05 & 53.49 \\
\hline $\operatorname{LR}_{\operatorname{chi}^{2}}(5)$ & 50.67 & 27.49 & 16.84 & 16.55 & 20.12 \\
\hline Prob $>\mathrm{Chi}^{2}$ & 0.0000 & 0.003 & 0.01 & 0.02 & 0.005 \\
\hline Pseudo $\mathrm{R}^{2}$ & -0.34 & -0.33 & -0.20 & -0.16 & -0.23 \\
\hline \# of Obs & 37 & 38 & 40 & 40 & 42 \\
\hline
\end{tabular}

$*=$ significant at 1 percent level, ${ }^{* *}=$ significant at 5 percent level, $* * *=$ significant at 10 percent level

Among bank internal factors, Table 5 shows that capital adequacy (EQTA), bank size (logTA), and bank's branches were significant factor for bank efficiency in all five years with its sign of coefficient consistency as expected and outlined in Table 1.

It is important to note that the coefficient of bank's branches were negative and significant. This suggests that too many branches of the banks of Bangladesh decreases the TE of banking industry. The policy implication suggests that banks should reconsider in opening their new branches.

The positive coefficient of bank size indicates that bank sizes enjoy economies of scale. The larger the bank size the higher the economies of scale and the higher the TE of bank.

\section{PTE Tobit Regression Results}

Two regressions were run for determining the significant factors for managerial efficiency (PTE). The first Tobit was run for determining the significance of CAMEL variables. The results of the first Tobit model was presented in Table 6. The Second Tobit was run in determining the significance of bank internal factors along with the CAMEL factors. The results of this CAMEL Plus model is provide in Table 7. 
TABLE 6

PTE REGRESSION RESULTS OF CAMEL MODEL

\begin{tabular}{|c|c|c|c|c|c|}
\hline & \multicolumn{5}{|c|}{ Year } \\
\hline Variables & 2008 & 2009 & 2010 & 2011 & 2012 \\
\hline EQTA & $\begin{array}{l}0.14 \\
(3.96)^{*}\end{array}$ & $\begin{array}{l}0.13 \\
(3.39)^{*}\end{array}$ & $\begin{array}{l}0.02 \\
(0.59)\end{array}$ & $\begin{array}{l}0.02 \\
(0.96)\end{array}$ & $\begin{array}{l}0.0005 \\
(0.02)\end{array}$ \\
\hline LLOSSTA & $\begin{array}{l}-0.002 \\
(-0.54)\end{array}$ & $\begin{array}{l}-0.002 \\
(-0.22)\end{array}$ & $\begin{array}{l}-0.01 \\
(-1.20)\end{array}$ & $\begin{array}{l}-0.01 \\
(-0.77)\end{array}$ & $\begin{array}{l}-0.0006 \\
(-0.35)\end{array}$ \\
\hline ROA & $\begin{array}{l}0.17 \\
(1.42) \\
\end{array}$ & $\begin{array}{l}-0.04 \\
(-0.58)\end{array}$ & $\begin{array}{l}0.17 \\
(0.66)\end{array}$ & $\begin{array}{l}0.30 \\
(1.38) \\
\end{array}$ & $\begin{array}{l}0.01 \\
(0.86)\end{array}$ \\
\hline EXPSTA & $\begin{array}{l}-0.08 \\
(-1.56)\end{array}$ & $\begin{array}{l}-0.12 \\
(-1.94) * * *\end{array}$ & $\begin{array}{l}-0.15 \\
(-0.99)\end{array}$ & $\begin{array}{l}-0.19 \\
(-1.32)\end{array}$ & $\begin{array}{l}-0.015 \\
(-0.12)\end{array}$ \\
\hline LOANDEP & $\begin{array}{l}0.04 \\
(2.89)^{*}\end{array}$ & $\begin{array}{l}0.13 \\
(6.38)^{*}\end{array}$ & $\begin{array}{l}0.03 \\
(1.44)\end{array}$ & $\begin{array}{l}-0.008 \\
(-0.25)\end{array}$ & $\begin{array}{l}0.01 \\
(0.88)\end{array}$ \\
\hline Constant & $\begin{array}{l}0.91 \\
(64.43) *\end{array}$ & $\begin{array}{l}0.88 \\
(62.79) *\end{array}$ & $\begin{array}{l}0.96 \\
(43.14)^{*}\end{array}$ & $\begin{array}{l}0.98 \\
(39.08) *\end{array}$ & $\begin{array}{l}0.95 \\
(45.73) *\end{array}$ \\
\hline $\begin{array}{l}\text { Log } \\
\text { Likelihood }\end{array}$ & 109.32 & 97.24 & 47.42 & 73.29 & 85.21 \\
\hline $\operatorname{LR}_{\operatorname{chi}^{2}}(5)$ & 30.38 & 53 & 10.85 & 8.66 & 4.89 \\
\hline Prob $>\mathrm{Chi}^{2}$ & 0.0001 & 0.0000 & 0.05 & 0.77 & 0.67 \\
\hline Pseudo $\mathrm{R}^{2}$ & -0.16 & -0.37 & -0.12 & -0.06 & -0.02 \\
\hline$\#$ of Obs & 37 & 38 & 40 & 40 & 42 \\
\hline
\end{tabular}

$*=$ significant at 1 percent level, $* *=$ significant at 5 percent level, $* * *=$ significant at 10 percent level

Table 6 shows that the capital adequacy (EQTA) and liquidity index (LOANDEP) were significant factors for PTE of the banking industry of Bangladesh during 2008-2009 whereas the cost inefficiency (EXPSTA) was a significant variable in 2009.

The negative coefficient of the cost efficiency index (EXPSTA) provides policy implication. Since higher cost decreases bank efficiency, bank management should provide extra care in incurring cost. 
TABLE 7

PTE REGRESSION RESULTS OF CAMEL PLUS MODEL

\begin{tabular}{|l|l|l|l|l|l|}
\hline & \multicolumn{5}{|c|}{ Year } \\
\hline Variables & 2008 & 2009 & 2010 & 2011 & 2012 \\
\hline EQTA & 0.16 & 0.30 & 0.14 & 0.02 & 0.12 \\
& $(3.27)^{*}$ & $(3.26)^{*}$ & $(2.13)^{* *}$ & $(0.73)$ & $(2.27)^{*}$ \\
\hline LLOSSTA & -0.008 & -0.01 & -0.01 & -0.007 & -0.01 \\
& $(-1.80)^{* * *}$ & $(-0.93)$ & $(-0.78)$ & $(-0.47)$ & $(0.84)$ \\
\hline ROA & 0.10 & -0.20 & 0.10 & 0.23 & 0.18 \\
& $(0.80)$ & $(-0.80)$ & $(0.39)$ & $(1.00)$ & $(0.95)$ \\
\hline EXPSTA & -0.03 & 0.09 & -0.01 & -0.15 & 0.03 \\
& $(-0.73)$ & $(0.10)$ & $(0.08)$ & $(-1.06)$ & $(0.22)$ \\
\hline LOANDEP & 0.06 & 0.08 & 0.02 & 0.02 & -0.01 \\
& $(4.26)^{*}$ & $(2.81)^{*}$ & $(0.97)$ & $(-0.71)$ & $(-0.56)$ \\
\hline $\operatorname{logTA}$ & 0.02 & 0.19 & 0.01 & 0.01 & 0.02 \\
& $5.19 *$ & $(3.55)^{*}$ & $(2.02)^{* *}$ & $(1.12)$ & $(2.51)^{*}$ \\
\hline Branch & -0.004 & -0.001 & -0.003 & -0.006 & -0.01 \\
& $(-2.33)^{* *}$ & $(-1.32)$ & $(-0.78)$ & $(-1.13)$ & $(-2.18)^{*}$ \\
\hline Constant & 0.72 & 0.71 & 0.77 & 0.90 & 0.72 \\
& $(18.28)^{*}$ & $(11.61)^{*}$ & $(9.07)^{*}$ & $(10.44) 8$ & $(6.84)^{*}$ \\
\hline Log & 99.54 & 54.34 & 50.41 & 83.71 & 53.49 \\
Likelihood & & & & & \\
\hline LR chi ${ }^{2}(5)$ & 50.67 & 27.49 & 16.86 & 1.90 & 20.12 \\
\hline Prob> Chi ${ }^{2}$ & 0.0000 & 0.0003 & 0.01 & 0.86 & 0.005 \\
\hline Pseudo R ${ }^{2}$ & -0.34 & -0.33 & -0.20 & -0.01 & -0.23 \\
\hline \# of Obs & 37 & 38 & & & \\
\hline
\end{tabular}

$*=$ significant at 1 percent level, $* *=$ significant at 5 percent level, $* * *=$ significant at 10 percent level

Among bank internal factors, Table 7 shows that capital adequacy (EQTA), bank size (logTA), and bank's branches were significant factor for bank efficiency with its sign of coefficient consistency as expected and outlined in Table 1.

It is important to note that the coefficient of bank's branches was negative and significant. This suggests that too many branches of the banks of Bangladesh decreases the PTE of banking industry. The policy implication suggests that banks should reconsider opening their new branches.

The positive coefficient of bank size indicates that bank sizes enjoy economies of scale. The larger the bank size the higher the economies of scale and the higher the PTE of bank.

\section{CONCLUSIONS}

This paper investigated the banking industry efficiency and the significant factors that determined the efficiency of the banking industry of Bangladesh during 2008-2015 employing the two stage DEA method.

First, technical efficiency (TE) and the pure technical efficiency (PTE) scores of each bank were obtained by DEA with the inputs of labor, fixed capital, and deposits. The results of the TE score revealed that the mean TE score of the banking industry of Bangladesh ranged between 96.7 percent and 98.6 percent during 2008-2012. This suggests that the technical inefficiency of the banking sector of Bangladesh ranged between 3.3 percent and 1.4 percent. Similar results were found for the median. The median technical efficiency ranged from 96.6 percent to 98.6 percent. 
The DEA results of the PTE score shows that the average pure technical efficiency (PTE) of the banking sector of Bangladesh, in Table 3, was relatively stable and it fluctuated between 98.1 percent and 99.3 percent during 2008-2012. This suggests that the managerial inefficiency of the banking sector of Bangladesh ranged between 0.7 percent and 1.9 percent. Similar results were found for the median PTE. The median PTE ranged from 98.3 percent to 99.9 percent.

A comparative summary of the TE and the PTE, Table 2 and Table 3, score reveals the following: (1) The PTE of the banks dominates the TE in the banking sector of Bangladesh. That is, banks of Bangladesh were managerially more efficient than TE. This is reflected from the fact that the mean PTE ranged from 98.1 percent to 99.3 percent whereas the mean TE fluctuated between 96.7 percent and 98.6 percent. (2) The banking sector of Bangladesh is dominated by the DRS. From 50 percent to 83 percent of banks of Bangladesh operated under the DRS during 2008-2012 compared to 0 percent 26 percent of banks which operated under the IRS.

Tobit regressions results revealed that most of the CAMEL variables were significant factors for the efficiency of the banking industry of Bangladesh.

In determining TE and PTE, the paper found that Capital adequacy (EQTA), asset quality (LLOSSTA), management ability (ROA), cost inefficiency (EXPSTA), and bank liquidity (LOANDEP) were significant determinants for bank technical efficiency in 2008. All variables affected bank efficiencies positively LLOSSTA and EXPTA.

Asset quality (LLOSSTA) and management ability (ROA), were significant determinants for bank TE during 2011 and 2012

Capital adequacy (EQTA) and liquidity index (LOANDEP) were significant factors for PTE of the banking industry of Bangladesh during 2008-2009 whereas the cost inefficiency (EXPSTA) was a significant variable in 2009.

Among bank internal factors, bank size (logTA) and bank branches (Branch) were significant factors in determining both TE and PTE of the banking industry of Bangladesh.

The negative coefficient of bank branch (Branch) and asset quality (LLOSSTA) provides policy implication for bank management. Since bank branches and LLOSSTA decrease the efficiencies, both TE and PTE, of the banking industry of Bangladesh, the policy implication suggests that bank management should be more cautious and should lend more time scrutinizing factors in opening new branches and loan advances to customers as the coefficient of these variables were negative. 


\section{REFERENCES}

Aigner, D.J., Lovell, C.A.C., \& Schmidt, P. (1977). Formulation and estimation of stochastic frontier production function models. Journal of Econometrics, 6, 21-37.

Aly, H. Y., Grabowski, R., \& Ragan, N. (1990). Technical, Scale and allocative efficiencies in U.U Banking: An Empirical Investigation. Review of Economic and Statistics, 72(2), 211-218.

Andries, A.M., \& Cocris, V. (2010). A comparative Analysis of the Efficiency of Romanian Banks. Romanian Journal of Economic Forecasting, 4, 54-75.

Banker, R.D., Charnes, A., \& Cooper, W.W. (1984). Some models for estimating technical and scale efficiencies in data envelopment analysis. Manage Science, 30(9), 1078-1092.

Barr, R., Siem, K. A., \& Zimmel, S.A. (2002). Evaluating the Productive Efficiency and performance of U.S. Commercial Banks. Managerial Finance, 28(8), 3-25.

Battese, G.E., \& Coelli, T.J. (1992). Frontier production functions, technical efficiency and panel data: With application to paddy farmers in India. Journal of Productivity Analysis, 3, 153-169.

Berger, A.N., \& Humphry, D.B. (1992). Measurement and Efficiency issues in commercial banking, Output measurement in the service Sectors. National bureau of Economic Research, Chicago University Press, Chicago, IL, pp.245-279

Berger, A.N., \& Humphry, D.B. (1997). Efficiency of Financial Institutions: International Survey and Directions for future Research. European Journal of Operational Research, 98, 175-212.

Bhattacharyya, A., Lovell, C.A.K., \& Sahay, P. (1997). The Impact of Liberalization on Productive Efficiency of Indian Commercial Banks. European Journal of Operations Research, 98, 113 127.

Bonin, J., I. Hassan., \& Wachtel, P. (2005). Bank performance, Efficiency and ownership in transition countries. Journal of Banking and Finance, 29, 31-53.

Casu, B., \& Girardone, C. (2002). A comparative study of cost efficiency Italian banks Conglomerates. Managerial Finance, 28(9), 3-23.

Charnes, A., Cooper, W.W., \& Rhodes, E. (1978). Measuring efficiencies of decision making Units. European Journal of Operational Research, 2(6), 429-444.

Chen, T., \& Yeh, T. (2008). A study of Efficiency Evaluation in Taiwan Banks. International Journal of Service Industry Management, 9(5), 402-415.

El-gamal \& Inanoglu. (2004). Islamic banking in Turkey: Boon or Bane for the financial Sector: Proceedings of the firth Harvard University forum on Islamic Finance. Cambridge: Center for Middle Eastern Studies, Harvard University.

Kumer, S., \& Gulati, R. (2008). An Examination of Technical, Pure Technical, and Scale Efficiencies in Indian Public Sector Banks using Data Development Analysis.

Kumbhakar, S.C., \& Sarkar, S. (2003). Deregulation, Ownership, and Productivity Growth in the banking Industry: Evidence from India. Journal of Money, Credit and banking, 35(3), 403-424.

Merger, A.N., \& Mester, L.J. (1997). Inside the black box: What determine differences in the Efficiency of Financial Institutions. Journal of Banking and Finance, 21(7), 895-94.

Merger, A.N., \& Mester, L.J. (2003). Explaining the dramatic changes in performance of U.S. Banks: Technological Changes, Deregulation and Dynamic changes in Competition. Journal of Financial Intermediation, 12(1), 57-95.

Pitt, M.M., \& Lee, L.F. (1981). Measurement and sources of technical inefficiency in the Indonesian weaving industry. Journal of Development Economics, 9, 43-64.

Ram Mohan, T.T., \& Roy, S.C. (2004). Comparing performance of Public and Private Sector banks: A Revenue Maximization Efficiency Approach. Economic and Political Weekly, 39(12), 37-48. 
Rossi, S., Schwaiger, M., \& Winkler, G. (2005). Managerial Behavior and cost/profit efficiency in the banking sector of Central and Eastern European countries. Working paper 96, Oesterreichische National Bank.

Saha, S., \& Ravishankar, T.S. (2000). Rating of Indian commercial Banks: A DEA approach. European Journal of Operations Research, 124, 312 -320.

Samad, A. (2004). Bahrain Commercial Bank’s Performance during 1994-2001. Credit and financial Management Review, 10(1), 30-40.

Samad, A. (2010). Estimate of Production efficiency: Evidence from Grameen Bank Microfinancing. Global Review of Business and Economic Research, 6(2), 183-189.

Samad, A. (2007). Comparative Analysis of Domestic and Foreign Bank Operations in Bangladesh. Global Journal of Finance and Economics, 4(1), 37-46.

Samad, A. (2009). Measurement of Inefficiencies in Bangladesh Banking Industry Using Stochastic Frontier Production Function. Global Journal of Business and Research, 3(1), 41-48.

Sarkar, J., Sarkar, S., \& Bhaumik, S.K. (1998). Does ownership always matter? Evidence from Indian banking Industry. Journal of comparative economics, 26, 213-27.

Schumpeter, J.A. (1911). The Theory of Economic Development. Harvard University Press, Cambridge, MA.

Shanmugam, K.R., \& Das, A. (2004). Efficiency of Indian Commercial Banks during the reform period. Applied Financial Economics, 14, 681-686.

Sufian, F., \& Abdul Majid, M.Z. (2006). Bank ownership, characteristics and performance: A comparative analysis of domestic and foreign Islamic banks in Malaysia. Journal of King Abdul Aziz University-Islamic Economics, 21(2), 3-38.

Sufian, F. (2009). Determinants of bank efficiency during unstable macroeconomic environment: Empirical evidence from Malaysia. Research in International Business and Finance, 23, 54-77. 


\section{APPENDIX}

TABLE 1

DESCRIPTIVE STATISTICS OF INPUTS AND OUTPUTS

\begin{tabular}{|c|c|c|c|c|c|}
\hline Year & 2008 & 2009 & 2010 & 2011 & 2012 \\
\hline \multicolumn{6}{|l|}{ Labor } \\
\hline Mean & 2517.442 & 2628.233 & 2847.884 & 3049.698 & 3327.884 \\
\hline Median & 979.0000 & 1215.000 & 1511.000 & 1624.000 & 1881.000 \\
\hline SD & 4176.852 & 4123.668 & 4081.150 & 4367.462 & 4665.024 \\
\hline \multicolumn{6}{|c|}{ Fixed Capital } \\
\hline Mean & 1021.842 & 1957.792 & 2564.622 & 3542.017 & 3847.588 \\
\hline Median & 541.0000 & 1033.000 & 1722.000 & 2056.000 & 2362.500 \\
\hline SD & 1006.877 & 2720.322 & 2928.449 & 4361.657 & 4611.802 \\
\hline \multicolumn{6}{|c|}{ Deposits } \\
\hline Mean & 57344.09 & 69318.74 & 83927.67 & 101991.3 & 122899.7 \\
\hline Median & 42435.00 & 53900.00 & 65126.00 & 81127.00 & 97624.00 \\
\hline SD & 64489.42 & 73673.09 & 87332.87 & 101595.6 & 116527.0 \\
\hline \multicolumn{6}{|c|}{ Outputs } \\
\hline \multicolumn{6}{|c|}{$\begin{array}{l}\text { Loans } \\
\text { advances }\end{array}$} \\
\hline mean & 46599.37 & 53450.30 & 73519.12 & 86302.14 & 96692.19 \\
\hline Median & 37141.00 & 43958.00 & 60327.00 & 76525.00 & 90642.00 \\
\hline SD & 46177.48 & 48520.78 & 65534.19 & 73418.76 & 83700.07 \\
\hline \multicolumn{6}{|c|}{ Investments } \\
\hline Mean & 10159.79 & 13471.74 & 13294.58 & 19392.63 & 25539.02 \\
\hline Median & 6135.000 & 9346.000 & 9216.000 & 12199.00 & 18403.00 \\
\hline SD & 17181.75 & 19896.50 & 18869.56 & 26488.95 & 29260.05 \\
\hline
\end{tabular}

* All variables are in log million TK, the local currencies of Bangladesh, except labor. 
TABLE 2

TECHNICAL EFFICIENCY OF BANKING INDUSTRY DURING 2008-2012

\begin{tabular}{|c|c|c|c|c|c|}
\hline & Year & & & & \\
\hline Bank's name & 2008 & 2009 & 2010 & 2011 & 2012 \\
\hline Sonali Bank & & 0.962521 & 1 & 0.983026 & 0.981531 \\
\hline Janata Bank & 0.9576 & 0.996356 & 0.996356 & 0.985381 & 0.985236 \\
\hline Agrani Bank & 0.9655 & 1 & 1 & 1 & 0.998533 \\
\hline Rupali Bank & 0.9519 & 0.975528 & 0.975528 & 0.974743 & 0.962246 \\
\hline Pubali Bank Ltd & 0.9638 & 0.988043 & 0.988043 & 0.978486 & 0.97356 \\
\hline Uttara Bank Ltd & 0.9579 & 1 & 1 & 0.986792 & 1 \\
\hline A B Bank Ltd & 0.9658 & 0.988601 & 0.988601 & 0.979173 & 0.965892 \\
\hline National Bank Ltd & 0.9658 & 1 & 1 & 0.994638 & 0.998386 \\
\hline The City Bank Ltd & 0.9571 & 0.988783 & 0.988783 & 0.985524 & 0.961726 \\
\hline International Finance Improvement Bank Ltd & 0.9705 & 0.981288 & 0.981288 & 0.97897 & 0.960165 \\
\hline United commercial Bank Ltd & 0.96157 & 0.97752 & 0.97752 & 0.974274 & 0.98833 \\
\hline Eastern Bank Ltd & 0.97299 & 1 & 1 & 1 & 0.993049 \\
\hline National Credit \& commerce Bank Ltd & & 1 & 1 & 0.995081 & 0.991973 \\
\hline Prime Bank Ltd & 0.97387 & 0.97846 & 0.97846 & 1 & 0.982345 \\
\hline Southeast bank Ltd & 0.97124 & 0.991051 & 0.991051 & 0.987624 & 0.963938 \\
\hline Dhaka Bank Ltd & 0.96647 & 0.979986 & 0.979986 & 0.973187 & 0.944825 \\
\hline Dutch Bangladesh Bank Ltd & 0.95766 & 0.973254 & 0.973254 & 0.962111 & 0.9876 \\
\hline Mercantile Bank Ltd & 0.96598 & 0.982893 & 0.982893 & 0.983575 & 0.974544 \\
\hline Standard Bank Ltd & 0.968 & 0.982961 & 0.982961 & 0.982893 & 0.954486 \\
\hline One Bank Ltd & 0.95403 & 0.978539 & 0.978539 & 0.974807 & 0.948081 \\
\hline Bangladesh commerce bank Ltd & 0.95748 & 0.941602 & 0.941602 & 0.967581 & 0.986115 \\
\hline Mutual Trust Bank Ltd & 0.96507 & 0.995964 & 0.995964 & 0.99404 & 0.959238 \\
\hline The Premium bank Ltd & 0.97156 & 0.988105 & 0.988105 & 0.981216 & 0.978167 \\
\hline Bank Asia ltd & 0.97337 & 0.990763 & 0.990763 & 0.980349 & 0.949144 \\
\hline Trust bank Ltd & 0.96314 & 0.980748 & 0.980748 & 0.976257 & 1 \\
\hline Jamuna Bank Ltd & 0.95574 & 0.984351 & 0.984351 & 0.982594 & 0.966741 \\
\hline Brack Bank Ltd & 0.97102 & 0.986642 & 0.986642 & 0.976751 & 0.9594 \\
\hline Islami Bank Bangladesh & 0.97138 & 0.953428 & 0.953428 & 0.958699 & 0.958216 \\
\hline ICB Islamic Bank & 1 & 0.95573 & 0.95573 & 1 & 0.953497 \\
\hline Al-Arafah Bank & 0.96972 & 0.94619 & 0.94619 & 0.950232 & 0.961973 \\
\hline Social Islamic Bank & 0.95644 & 0.947793 & 0.947793 & 0.953331 & 0.959284 \\
\hline $1^{\text {st }}$ Security Islamic Bank & 0.97224 & 0.953625 & 0.953625 & 0.953843 & 0.965244 \\
\hline Shahjalal Islamic Bank & 0.96556 & 0.951348 & 0.951348 & 0.951885 & 0.95607 \\
\hline EXIM Bank & 0.96878 & 1 & 1 & 0.972101 & 0.969406 \\
\hline Standard \& Chartered bank & & & & 0.976362 & 0.943452 \\
\hline Habib Bank & 1 & 0.989905 & 0.989905 & & \\
\hline State Bank of India & & & & & 0.973296 \\
\hline Commercial bank of Cylone & 0.94649 & 1 & 1 & 1 & 1 \\
\hline National bank of Pakistan & & & & 1 & 1 \\
\hline Citi Bank N.A & 1 & 1 & 1 & 1 & 0.986165 \\
\hline Woori Bank & & 1 & 1 & 1 & 1 \\
\hline Hong Kong \& Sanghai bank & 0.97972 & 0.979695 & 0.979695 & & 1 \\
\hline Bank al Falah & 0.94975 & 0.932115 & 0.932115 & 0.911365 & \\
\hline Mean of all banks & & & & & \\
\hline
\end{tabular}

